Nat. Hazards Earth Syst. Sci. Discuss., https://doi.org/10.5194/nhess-2018-270

Manuscript under review for journal Nat. Hazards Earth Syst. Sci.

Discussion started: 25 September 2018

(C) Author(s) 2018. CC BY 4.0 License.

(c) (1)

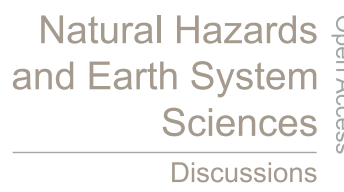

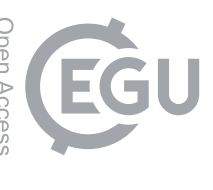

\title{
1 Influence of shearing rate on the residual strength characteristic of 2 three landslides soils in loess area
}

4 Baoqin Lian ${ }^{1,2}$, Jianbing Peng ${ }^{1}$, Xingang Wang $^{3 *}$, Qiangbing Huang ${ }^{1}$

${ }^{1}$ College of Geological Engineering and Surveying, Chang'an University, Key Laboratory of Western China Mineral

Resources and Geological Engineering, Xi'an 710054, China

8

$9 \quad{ }^{2}$ Department of Geology \& Geophysics, Texas A\&M University, College Station, TX 77843-3115, United States

$11{ }^{3}$ State Key Laboratory of Continental Dynamics, Department of Geology, Northwest University, Xi'an 710069, China

12

13 *Corresponding author: Xingang Wang (xgwang@nwu.edu.cn); ORCID:0000-0002-1744-8712

14

15

16

17

18 
Nat. Hazards Earth Syst. Sci. Discuss., https://doi.org/10.5194/nhess-2018-270

Manuscript under review for journal Nat. Hazards Earth Syst. Sci.

Discussion started: 25 September 2018

(c) Author(s) 2018. CC BY 4.0 License.

(c) (9)

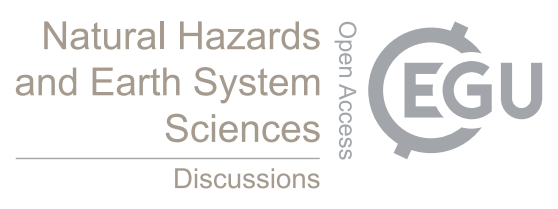

19 Abstract

20 In order to investigate the effect of the shearing rate on the residual shear strength of slip zone soils, a series ring shear tests

21 were carried out on slip zone soils from three landslides in loess area at the two shearing rates $(0.1 \mathrm{~mm} / \mathrm{min}$ and $1 \mathrm{~mm} / \mathrm{min})$.

22 The slip zone soil specimens used in present study were from the northwest of China. Results indicated that the shear 23 displacement to achieve the residual stage for specimens with higher shearing rate is greater than that of the lower rate.

24 Relationship between the residual friction coefficients and normal stress shows that the residual friction coefficients for all 25 specimens under the lower normal stress were greater than that under the higher normal stress at two shearing rate. 26 Furthermore, the difference in the residual friction angle $\phi_{\mathrm{r}}$ at the two shearing rates, $\phi_{\mathrm{r}}(1)-\phi_{\mathrm{r}}(0.1)$, under each normal 27 stress level were either positive or negative values, with the maximum absolute value of $\phi_{\mathrm{r}}(1)-\phi_{\mathrm{r}}(0.1)$ reach up to $2.218^{\circ}$. 28 However, the difference $\phi_{\mathrm{r}}(1)-\phi_{\mathrm{r}}(0.1)$ under all normal stresses was negative, which indicates that the residual shear 29 parameters reduced with the increasing of the shearing rate in loess area.

Keywords: Residual shear strength; Ring shear test; Shearing rate; Normal stress; Slip zone soils 
Nat. Hazards Earth Syst. Sci. Discuss., https://doi.org/10.5194/nhess-2018-270

Manuscript under review for journal Nat. Hazards Earth Syst. Sci.

Discussion started: 25 September 2018

(c) Author(s) 2018. CC BY 4.0 License.

\section{Introduction}

Residual strength of soil is of great significance for evaluating the reactivating potential of the slope, in which consists of pre-existing sliding surface. Residual strength of a landslide soil is defined as the minimum constant value of strength along the slip plane, in which the soil particles are reoriented and subjected to sufficiently large displacements in relatively low shearing rate (Skempton, 1985) .

Numerical studies have been done to assess the residual strength through the laboratory tests using ring shear tests and reversal direct shear tests (Chen and Liu, 2013; Vithana et al., 2012). It is a generally accepted fact that the measurement of the residual strength is most preferred done with a ring shear test since it allows the soil specimen be sheared at unlimited displacement which can simulate the field conditions more accurately (Lupini et al., 1981;Tiwari and Marui, 2005;Bhat, 2013; Sassa et al., 2004). Until now, several relationships between the residual strength and soil index parameters have been reported in the literature with a wide range of soil by using various kinds of ring shear apparatus (Hoyos et al., 2014;Jiang et al., 2016;Kimura et al., 2015;Li et al., 2013;Skempton, 1964). Furthermore, many studies have shown that the shearing rate may or may not affect the minimum value of soil strength at residual states (Suzuki et al., 2007;Grelle and Guadagno, 2010;Gonghui et al., 2010;Bhat, 2013;Tika and Hutchinson, 1999;Lemos, 1985;Morgenstern and Hungr, 1984;Tika, 1999).

From the high shearing rate aspect in the geotechnical literatures, Morgenstern and Hungr (1984) carried out ring shear tests on two types of coarse sand in high velocity and found that the frictional behavior was not affected by either the velocity or the normal stress. However, there were many researchers asserted that the effect of shearing rate on the shear behavior of soil cannot be ignored. For example, Skempton (1985), Tika and Hutchinson (1999) found that the faster shearing rate above $100 \mathrm{~mm} / \mathrm{min}$ may bring about great qualitative changes in the residual behavior. Moreover, Tika et al. (1996) conducted fast ring shear tests on a wide range of natural soils and concluded that there are three types of rate effects on the residual strength, namely, a positive rate effect (the residual strength of soil at fast rate is higher than that of the slow rates), a neutral rate effect (the residual strength of soil is independent of the shearing rate) and a negative rate effect ( the residual strength of the soil at higher speed is lower than that of the lower speed). Recently, Gratchev Ivan and Sassa (2015) reported that the residual strength of the clay decrease with the shear rate increase from 0.2 to $5 \mathrm{~mm} / \mathrm{s}$.

On the other hand, in the slow shearing rate range, Skempton (1985) reported that variation in the value of the residual 
Nat. Hazards Earth Syst. Sci. Discuss., https://doi.org/10.5194/nhess-2018-270

Manuscript under review for journal Nat. Hazards Earth Syst. Sci.

Discussion started: 25 September 2018

(c) Author(s) 2018. CC BY 4.0 License.
Natural Hazards

and Earth System

Sciences

Discussions

friction angle for shearing rates in a range of 0.05 to $0.35 \mathrm{~mm} / \mathrm{min}$ was less than a $5 \%$ and concluded that the impact of shearing rate on the residual strength of clay is almost negligible within slow rate displacement. Similarly, Bhat (2013) concluded that there is hardly increase in residual strength of kaolin clay with the shearing rate ranging from $0.233 \mathrm{~mm} / \mathrm{min}$ to $0.586 \mathrm{~mm} / \mathrm{min}$. Furthermore, Yokota et al. (1995) showed that residual strength is not affected by shearing rate lower than $1.01 \mathrm{~mm} / \mathrm{min}$ in ring-shear tests. Except the above studies, other similar results were also found in clays that the residual strength is independent of the shearing rate (Chen and Liu, 2013;Tiwari and Marui, 2001). However, Suzuki et al. (2001) has reported the shearing rate ranging from 0.02 to $2.0 \mathrm{~mm} / \mathrm{min}$ significantly affected the residual strength of kaolin clay and mud stone. Moreover, Gonghui et al. (2010) also has reported that the residual shear strength of the weathered serpentinite is positively dependent on the shear rate in the slow rate.

On general, the effect of the shearing rate on the residual strength of the soil has not been sufficiently studied in high and slow shearing rate range. Furthermore, except for a few studies, researchers have not widely reported the impact of the shearing rate on the residual strength of loess soil in relatively lower shearing rate range from $0.1 \mathrm{~mm} / \mathrm{min}$ to $1 \mathrm{~mm} / \mathrm{min}$. However, it should be noted that the residual strength parameters obtained from using different shearing rate may be adopted to provide a guide for designing some precision engineering which require high accuracy of the design parameters, thus, the effect of the shearing rate on the residual strength of soils should be fully understood to determine the parameters with high reliability. In addition, residual strength of soil plays a key role in assessing the stability analysis and evaluating the reactivation potential of landslides which consists of pre-existing slip plane surface. Therefore, accurate determination of the residual strength parameters and their dependence on the shearing rate may affect the stability evaluation of landslides. Thus, it is necessary to study the residual strength variation of loess in rate of shearing in order to have a good understanding of the suitable approach for the residual strength measurement.

In this backdrop, the present study investigated the effect of the shearing rate on the residual strength of soil samples obtained from three landslides in

loessic- developed areas at two different shearing rates $(0.1 \mathrm{~mm} / \mathrm{min}$ and $1 \mathrm{~mm} / \mathrm{min})$ by using a ring shear apparatus. The main objective of this study was to examine the change in the residual strength parameters of loess at different shearing rates and their relationship with the normal stress in naturally drained ring shear tests. 
Nat. Hazards Earth Syst. Sci. Discuss., https://doi.org/10.5194/nhess-2018-270

Manuscript under review for journal Nat. Hazards Earth Syst. Sci.

Discussion started: 25 September 2018

(c) Author(s) 2018. CC BY 4.0 License.

(c) (i)

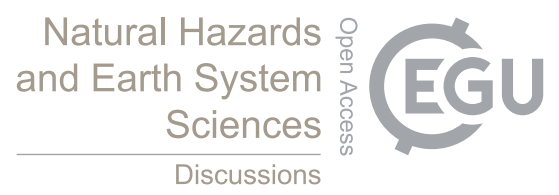

\section{Geological setting of landslide sites}

Soil samples from three reactivated landslides in the northwest of China were selected for this study. Soil samples used for the ring shear tests and index measuring tests predominantly consist of loess deposits and were collected in a disturbed condition. For convenience, the names of landslide sites were abbreviated into Djg, Ydg, and Dbz. Figure 1 shows the study sites and some views of the landslides.

\section{Dingjiagou landslide}

The Djg landslide, located at the mouth of Dingiia Gully in Yan'an of China, is geologically composed of upper loess and lower sand shale in the Yan-chang formation. The dustpan-shaped landslide is inclined to the east, with its inclination $75.85^{\circ}$. The landslide is $350 \mathrm{~m}$ in width, $180 \mathrm{~m}$ in length, $70 \mathrm{~m}$ in elevation. The average thickness of slip mass is around 20 $\mathrm{m}$, and the volume of landslide totaled approximately $105 \times 10^{4} \mathrm{~m}^{3}$. The slip mass is mainly constituted by loess, whereas the sliding bed consists of sand shale in Yan-chang formation. The thickness of the sliding zone varied from 30 to $50 \mathrm{~cm}$. The front lateral region of the main slide section of the Djg landslide, where the sampling was performed, was found to be silty clay.

\section{Yandonggou landslide}

The Ydg landslide is located in the Qiaogou town of Yan'an in Shaan xi province of China. The top and the toe altitude of the landslide are about $1165 \mathrm{~m}$ and $1110 \mathrm{~m}$ above the sea level, with the height difference between the toe and the top of landslide about $55 \mathrm{~m}$. The slides have well-developed boundaries with the main sliding direction of $240^{\circ}$ and slope angle of respectively. Multiple landslide activities had occurred in this site, and the soil samples used in this study were collected from $\mathrm{Q}_{2}$ loess stratum within the slide ranged from 4.5 to $18 \mathrm{~m}$ in height.

\section{Dabuzi landslide}

The Dbz landslide is located in the middle part of Shaanxi province (about 108 $51^{\prime} 36^{\prime \prime}$ east longitude and $34^{\circ} 28^{\prime} 48^{\prime \prime}$ north latitude), China, which is a semi-arid zone dominated by loessic geology. In this region, the investigated site is classified as a typical loess tableland with quaternary stratum. The sedimentary losses in this area are grey yellow, and the exposure stratum 
Nat. Hazards Earth Syst. Sci. Discuss., https://doi.org/10.5194/nhess-2018-270

Manuscript under review for journal Nat. Hazards Earth Syst. Sci.

Discussion started: 25 September 2018

(c) Author(s) 2018. CC BY 4.0 License.

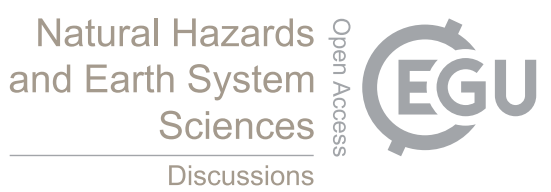

109 in this area has been divided into two stratigraphic units, namely, the upper late Pleistocene $\left(\mathrm{Q}_{3}\right)$ loess and the lower

110 mid-Pleistocene $\left(\mathrm{Q}_{2}\right)$ loess, of which the $\mathrm{Q}_{3}$ loess is younger. The $\mathrm{Q}_{3}$ loess is closest to the surface and is up to approximately

$11112 \mathrm{~m}$ thick, while the thickness of $\mathrm{Q}_{2}$ loess may reach an upper limit of about $50 \mathrm{~m}$ (Leng et al., 2018). The loess in this area

112 have well-developed vertical joints (Sun et al., 2009). The travel distance and the maximum width of the slip mass are

113 roughly estimated to be $121.55 \mathrm{~m}$ and $133.46 \mathrm{~m}$, respectively. The armchair-shaped landslide shows an apparent sliding

114 plane, with an area of approximately $15,660 \mathrm{~m}^{2}$ and about $66.25 \mathrm{~m}$ maximum difference in elevation. The main direction of

115 this landslide is approximately $355^{\circ}$. The exposed slip zone in the side scarp of the landslide, where the sampling was done,

116 was found to be entirely in the $\mathrm{Q}_{2}$ loess stratum of the Dbz landslide site. The thickness of narrow- band slip zone loess is

117 less than $1.0 \mathrm{~cm}$, inclined at around $65^{\circ}$ to the horizontal direction. Since the band of slip zone is thin, mix soils which consist

118 of the slip zone soils, the very thin upper and lower parts of the loess are mingled together and served as the representative

119 samples of the slip zone loess in this site.
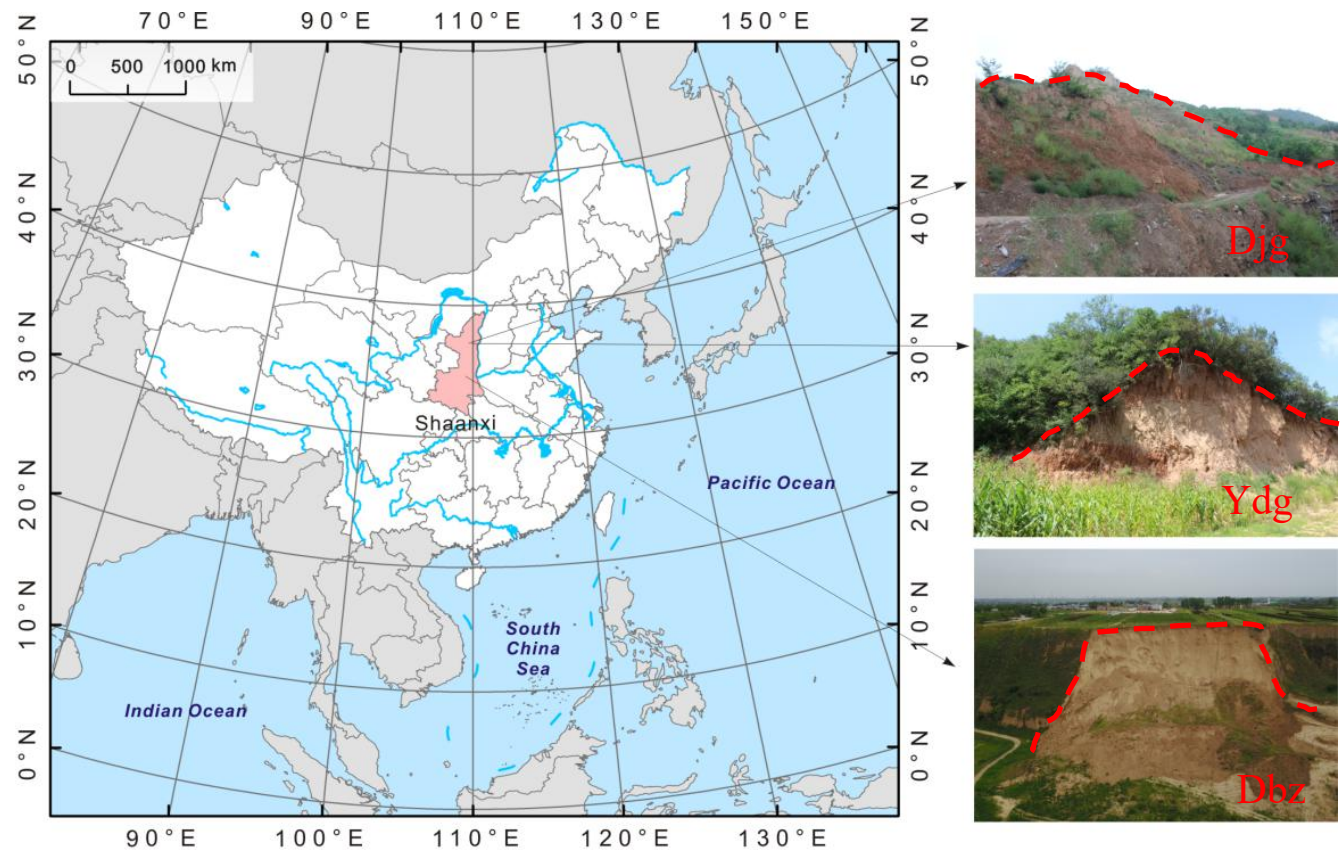

121 Figure 1. Location of study sites and some views of landslides

3. Experimental scheme

\subsection{Testing sample}


Nat. Hazards Earth Syst. Sci. Discuss., https://doi.org/10.5194/nhess-2018-270

Manuscript under review for journal Nat. Hazards Earth Syst. Sci.

Discussion started: 25 September 2018

(C) Author(s) 2018. CC BY 4.0 License.
Natural Hazards

and Earth System

Sciences

Discussions

The fact that the residual shear strength is independent of the stress history was reported by many researchers (Bishop et al., 1971; Vithana et al., 2012;Stark Timothy et al., 2005). Thus, disturbed loess samples from each of the three landslides weighing about $25 \mathrm{~kg}$ were collected from the slip surface soil of each slide and used to determine residual shear strength.

The soil samples were air-dried and then crushed with a mortar and pestle, and subsequently processing it through $0.5 \mathrm{~mm}$ sieve. Distilled water was added to the soil samples until desired density and water content were obtained. The physical parameters such as natural moisture content, specific gravity, bulk density, plastic limit, and liquid limit were determined in accordance with the Chinese National Standards (CNS) GB/T50123-1999 (standards for soil test methods) (SAC, 1999), but clay size was defined to be less than $2 u$ m followed ASTM, D422 (ASTM, 2007). Each soil sample was separated into clay (sub $0.002 \mathrm{~mm})$, silt $(0.002-0.075 \mathrm{~mm})$, and sand $(0.075-0.5 \mathrm{~mm})$ fractions. The physical indexes of the soil are listed in Table 1.

The grain size distribution of soil was measured using a laser particle size analyzer Bettersize 2000 (Dandong Bettersize Instruments Corporation, Dandong, China). The sieved soil samples were used to determine particle size distribution. In this study, soil samples were treated with sodium hexaphosphate, serving as a dispersant, to disaggregate the bond between the particles. The results show that the clay fraction in Djg landslide soil (24\%) is more than two times than that from Ydg (9\%) and Dbz (9.1\%). Furthermore, the particle size analyses illustrates that the percentage of silt-sized soil in three landslides ranged from $75.66 \%$ to $87.4 \%$. In addition, Ydg landslide soil consists of the greatest percentage of the sand fraction which reaches up to $10.55 \%$.

In present study, a total of twenty four specimens were tested at two shearing rate $(0.1 \mathrm{~mm} / \mathrm{min}$ and $1 \mathrm{~mm} / \mathrm{min})$ and under normal stresses ranged from $100 \mathrm{kN} / \mathrm{m}^{2}$ to $400 \mathrm{kN} / \mathrm{m}^{2}$ in a ring shear apparatus.

Table 1 Physical parameters of slip-zone loess

\begin{tabular}{c|c|c|c|c|c|c|c|c|c|c}
\hline sites & & & & & & & \multicolumn{5}{|c}{ Grain size fractions (\%) } \\
\cline { 7 - 11 } & $\rho_{d}$ & $W$ & $\rho$ & $G_{S}$ & $W_{L}$ & $W_{\mathrm{p}}$ & $<0.002 \mathrm{~m}$ & $0.002-0.005 \mathrm{~m}$ & $0.005-0.075$ & $0.075-0.5 \mathrm{~m}$ \\
\hline $\mathrm{Djg}$ & 1.74 & 19. & 2.0 & 2.6 & 3 & 20 & 24 & 11.48 & 64.18 & 0.34 \\
\hline $\mathrm{Ydg}$ & 1.47 & 18 & 1.7 & 2.7 & 3 & 19 & 9 & 5.28 & 75.17 & 10.55 \\
\hline
\end{tabular}


Nat. Hazards Earth Syst. Sci. Discuss., https://doi.org/10.5194/nhess-2018-270

Manuscript under review for journal Nat. Hazards Earth Syst. Sci.

Discussion started: 25 September 2018

(c) Author(s) 2018. CC BY 4.0 License.
Natural Hazards

and Earth System

Sciences

Discussions

(c) $\underset{\mathrm{BY}}{(i)}$

\begin{tabular}{l|l|l|l|l|l|l|l|l|l|l}
\hline Dbz & 1.48 & 16 & 1.7 & 2.7 & 3 & 21 & 9.1 & 6.4 & 81 & 3.5 \\
\hline
\end{tabular}

144 Notes: $\rho_{d}=$ dry density; $\mathrm{w}=$ moisture water content; $\rho=$ bulk density; $G_{S}=$ specific gravity; $\mathrm{W}_{\mathrm{L}}=$ liquid limit; $W_{\mathrm{p}}=$ plastic limit

\subsection{Testing apparatus}

The advantage of a ring shear test apparatus to measure residual shear strength including its ability to allow

148 unidirectional shearing of a soil specimen (Bishop et al., 1971;Tika, 1999;Suzuki et al., 2007;Bromhead, 1979). Thus, a ring

149 shear apparatus was used in this study.

An advanced ring shearing apparatus (SRS-150) manufactured by GCTS (Arizona, USA) was adopted in ring shear

151 tests and the photos of apparatus were shown in Fig.2, which consists mainly of a shear box with an outer diameter of 150

$152 \mathrm{~mm}$, an inter diameter of $100 \mathrm{~mm}$ and the maximal sample height of $250 \mathrm{~mm}$. The shearing box consists of the upper

153 shearing box and the lower shearing box. In the shearing process, the upper shearing box keeps still while the lower one

154 rotates. The apparatus, which provides effective specimen area of $98 \mathrm{~cm}^{2}$, is capable of shearing the specimen for large

155 displacement in single direction. The annular specimen is confined by inside and outside metal rings. Moreover, the

156 specimen is confined by bottom annular porous plates and top annular porous plates in which have sharp-edged radial metal

157 fins which protrude vertically into the top and bottom of the specimen at the shearing process. The normal stress, shearing

158 strength and shearing displacement can be monitored while shearing by computer. The measurement features of the ring

159 shear apparatus employed in this study are described as follows: shearing rate range from 0.001 to 360 degrees per minute,

$16010 \mathrm{kN}$ axial load capacity, 300 N.m continuous torque capacity, maximum normal stress of $1000 \mathrm{kN} / \mathrm{m}^{2}$. 
Nat. Hazards Earth Syst. Sci. Discuss., https://doi.org/10.5194/nhess-2018-270

Manuscript under review for journal Nat. Hazards Earth Syst. Sci.

Discussion started: 25 September 2018

(c) Author(s) 2018. CC BY 4.0 License.
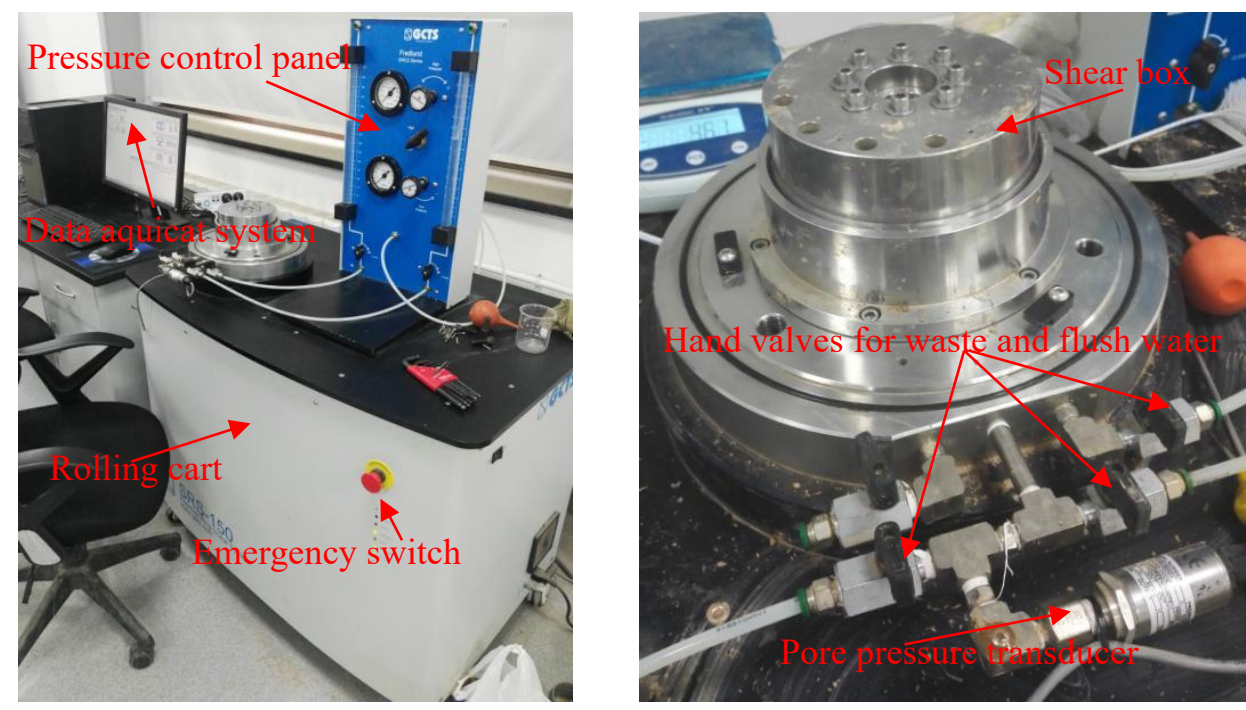

Figure 2. Ring shear apparatus (SRS-150)

\subsection{Testing procedure}

In present study, reconstituted samples of the sub $0.5 \mathrm{~mm}$ soil fraction were used in the testing as it was reported that the residual strength of the soil was unaffected by its initial structure (Bishop et al., 1971;Vithana et al., 2012). Specimens were first prepared by adding distilled water to the air-dried soil until the saturated moisture contents of the three landslide soils were obtained. Then, specimens were kept in a sealed container for at least one week to fully hydrate. Specimens are then reconstituted in the ring-shaped chamber of the apparatus by compaction. In order to make the sample uniform while packing, the sample was placed in three layers, and each layer was tamped under a vertical stress which is lower than the given normal stress to achieve the design height. The final height of the specimen in the ring shear apparatus after tamp varied but was typically about $20 \mathrm{~mm}$ (to achieve a specific bulk density). The specimen was then consolidated under a specific effective normal stress in a range of $100 \mathrm{kN} / \mathrm{m}^{2}$ to $400 \mathrm{kN} / \mathrm{m}^{2}$ until required consolidation was achieved. Then, the consolidated specimen is subjected to shearing under constant normal stress by rotating the lower half of the shear box attached to a gear, while the upper half remains still. In ring shear tests, the normal stress at the shearing was the same as at consolidation stage.

In this study, ring shear tests were performed in a single stage under drained condition and the samples were subjected to shear until the residual state was achieved. Drain condition of the shearing process is provided by two porous stones 
Nat. Hazards Earth Syst. Sci. Discuss., https://doi.org/10.5194/nhess-2018-270

Manuscript under review for journal Nat. Hazards Earth Syst. Sci.

Discussion started: 25 September 2018

(c) Author(s) 2018. CC BY 4.0 License.
Natural Hazards

and Earth System

Sciences

Discussions

attached on the top and the bottom platen of the specimen container. As for soil specimens with low permeability, the rate of excess pore pressure generation in the shear box may exceeded that of pore-pressure dissipation, this type of condition is identified as naturally drained condition in previous studies(Okada et al., 2004). Furthermore, Tiwari (2000) asserted that it was acceptable to use a shearing rate below $1.1 \mathrm{~mm} / \mathrm{min}$ to simulate the field naturally drained condition. Thus, shearing rates of $0.1 \mathrm{~mm} / \mathrm{min}$ and $1 \mathrm{~mm} / \mathrm{min}$ were used in this study to simulate the naturally drained condition of the slip zone soils.

\section{Results and discussions}

Twenty four specimens were tested to investigate the shear characteristics of the slip-zone soils in the ring shear apparatus. Tests results are shown in this section.

\subsection{Shear behavior}

Figures $3 \mathrm{a}, 4 \mathrm{a}$ and $5 \mathrm{a}$ show the typical shear characteristics of the slip-zone soils (shearing rate $0.1 \mathrm{~mm} / \mathrm{min}$ and 1 $\mathrm{mm} / \mathrm{min}$ ) obtained from three different locations, where, the shear stress is plotted against the shear displacement at the normal stress ranged from $100 \mathrm{kN} / \mathrm{m}^{2}$ to $400 \mathrm{kN} / \mathrm{m}^{2}$. It is a widely accepted fact that normal stress has effect on the shear behavior of the soil (Kimura et al., 2015;Stark Timothy et al., 2005;Stark et al., 2005;Eid, 2014), thus, the shear behavior of samples at the peak and residual stages, where, the determined peak friction coefficient as well as residual friction coefficient are plotted in Figure 3b, 4b, and 5b against the corresponding effective normal stresses. The friction coefficient is defined as the shear stress divided by the effective normal stress.

Figures $3 \mathrm{a}, 4 \mathrm{a}$ and $5 \mathrm{a}$ demonstrate that shear stress increases dramatically within small shear displacement and then reduces with shearing displacement, until residual conditions were achieved at large displacements. Furthermore, it is clear that peak strength as well as residual strength of the samples with high shearing rate is almost smaller than that of the samples with low rate. In Figures 3a, 4a and 5a, a clear drop can be seen, at any normal stress, for specimens obtained from all sites. It is obvious that Djg specimens showed greater peak-post drop than that of Ydg and Dbz specimens. According to the conclusion that the residual stage is attained if a constant shear stress is measured for more than half an hour (Bromhead, 1992), it can be seen that the shear displacement to achieve the residual stage for specimens with higher shearing rate is greater than that of the lower rate. For example, the minimum shear displacements for attaining residual condition for Djg specimens with low and high shearing rate were about $360 \mathrm{~mm}$ and $650 \mathrm{~mm}$, respectively. Under the shearing rate of 
Nat. Hazards Earth Syst. Sci. Discuss., https://doi.org/10.5194/nhess-2018-270

Manuscript under review for journal Nat. Hazards Earth Syst. Sci.

Discussion started: 25 September 2018

(c) Author(s) 2018. CC BY 4.0 License.

(c) (i)
Natural Hazards

and Earth System

Sciences

Discussions

$0.1 \mathrm{~mm} / \mathrm{min}$ and $1 \mathrm{~mm} / \mathrm{min}$, Ydg specimens need approximately $80 \mathrm{~mm}$ and $1,400 \mathrm{~mm}$ displacement to achieve residual stage. However, Dbz specimens require about $40 \mathrm{~mm}$ and $60 \mathrm{~mm}$ displacement to reach residual condition for low and high shearing rate, respectively.

\subsection{Effect of normal stress on the friction coefficients}

It can be seen from the Figures $3 \mathrm{~b}, 4 \mathrm{~b}$ and $5 \mathrm{~b}$ that the friction coefficients (peak and residual) are higher at lower effective normal stress levels. For example, the peak and residual friction coefficient of Djg landslide soils at the shearing rate of $0.1 \mathrm{~mm} / \mathrm{min}$ reduced from 0.569 to 0.32 and from 0.3 to 0.262 , respectively. Similarly, results obtained from other two landslides soils also showed that the friction coefficients decrease nonlinearly with the normal stresses. Furthermore, specimens with shearing rate of $0.1 \mathrm{~mm} / \mathrm{min}$ attained greater friction coefficients than that with shearing rate of $1 \mathrm{~mm} / \mathrm{min}$.

In order to get an insight into the effects of the normal stress on the slip zone shear strength, the shear behavior of the soil sheared at the normal stress of $100 \mathrm{kN} / \mathrm{m}^{2}$ and $400 \mathrm{kN} / \mathrm{m}^{2}$ were selected for analysis. At the normal stress of $100 \mathrm{kN} / \mathrm{m}^{2}$, Djg samples showed about $47.3 \%$ and $36.8 \%$ decrease in the friction coefficient from the peak friction coefficient at the shearing rate of 0.1 and $1 \mathrm{~mm} / \mathrm{min}$, respectively, which is greater than in the Ydg (about $9.8 \%$ and $10.3 \%$ ) and Dbz (about $2.4 \%$ and $3.2 \%$ ) samples. In Figures $3 b, 4 b$ and $5 b$, on average, it is obvious that the decrease of the friction coefficient from the peak strength to the residual strength in the Djg sample was almost $18.1 \%$ and $21.3 \%$ for the sample consolidated at normal stress of $400 \mathrm{kN} / \mathrm{m}^{2}$ under the shearing rate of $0.1 \mathrm{~mm} / \mathrm{min}$ and $1 \mathrm{~mm} / \mathrm{min}$ (Figure $3 \mathrm{~b}$ ), While the friction coefficient reduction in Ydg sample with low and high shearing rate were only about $4.1 \%$ and $4.8 \%$ (Figure $4 \mathrm{~b}$ ). And the friction coefficient reduction in Dbz samples with low and high rate were only approximately $5.6 \%$ and $6.0 \%$ (Figure $5 b$ ) from the peak strength, respectively. Based on the conclusion that the post-peak drop in strength of soil is only due to particle reorientation after the peak strength (Mesri and Shahien, 2003;Skepmton, 1964), the results in this study demonstrated that the Djg landslide soil existed the greater particle reorientation compared with that of other two landslide soils. 
Nat. Hazards Earth Syst. Sci. Discuss., https://doi.org/10.5194/nhess-2018-270

Manuscript under review for journal Nat. Hazards Earth Syst. Sci.

Discussion started: 25 September 2018

(C) Author(s) 2018. CC BY 4.0 License.
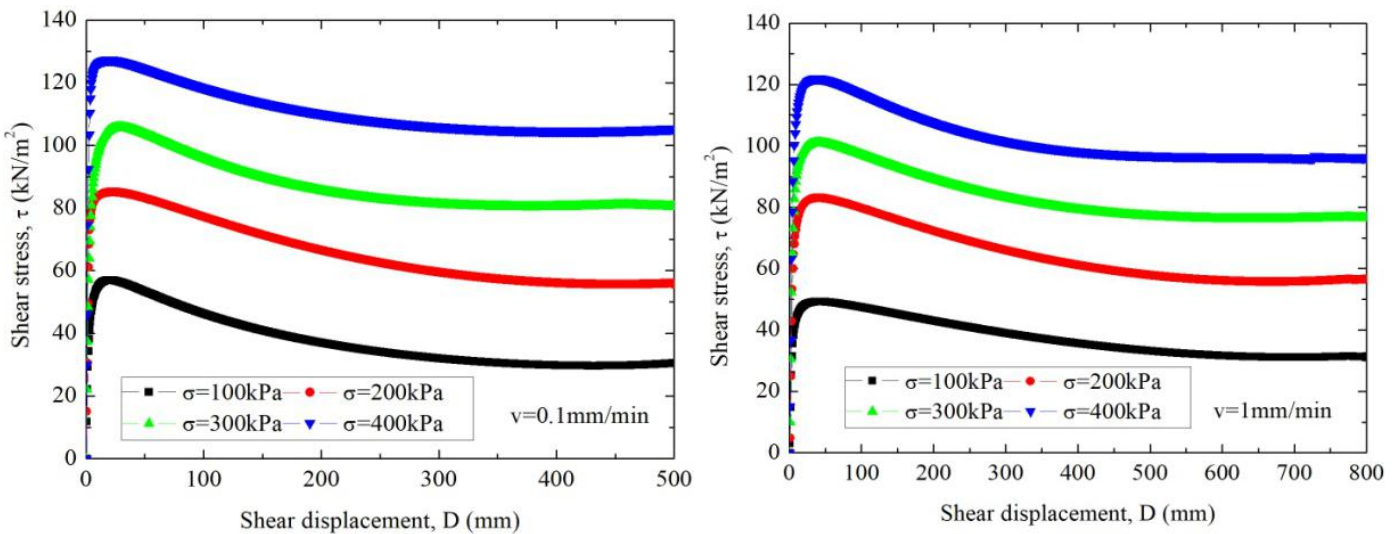

(a)Relationship between shear stress and shear displacement
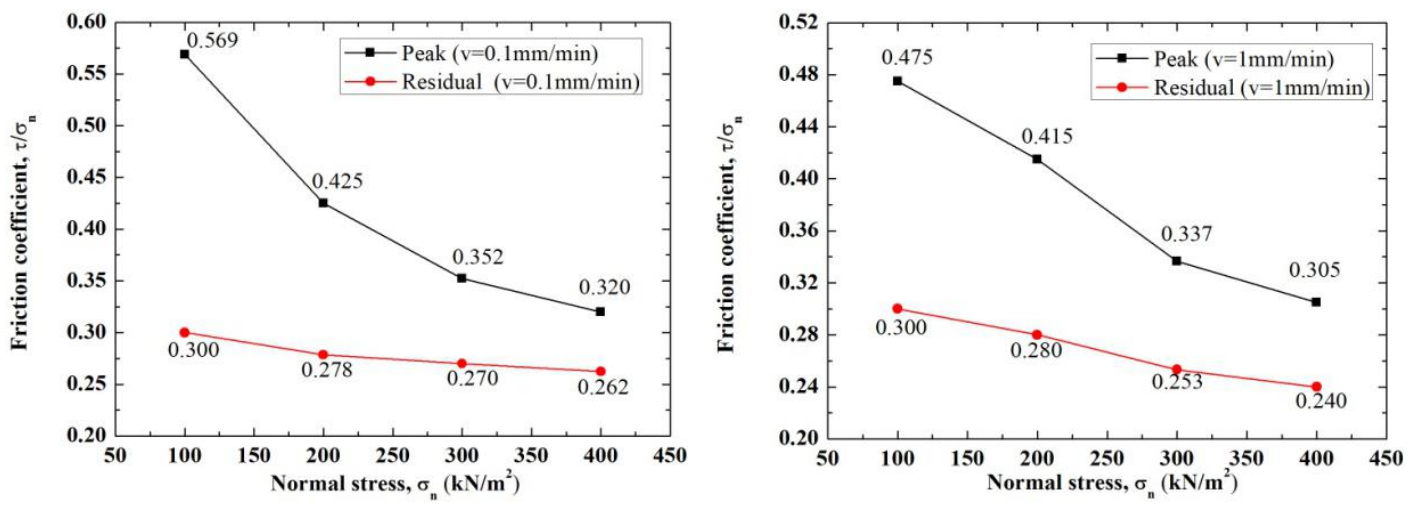

(b)Relationship between friction coefficient and normal stress

Figure 3. Shear behavior characteristics of Djg soil samples
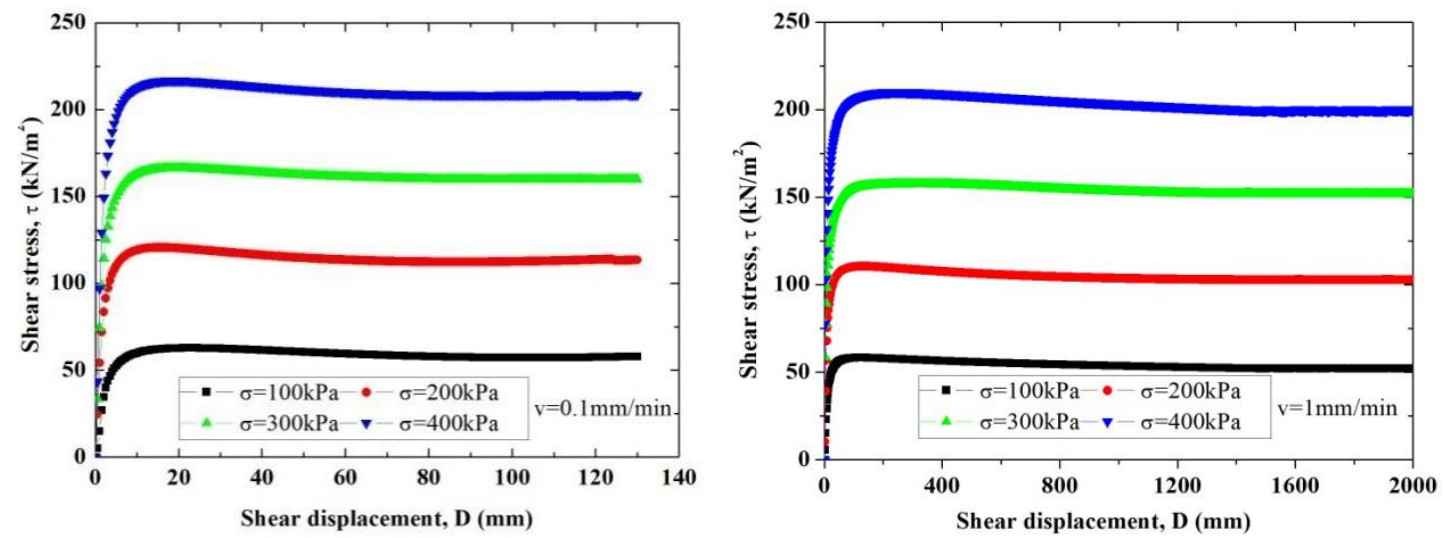

232 (a)Relationship between shear stress and shear displacement 
Nat. Hazards Earth Syst. Sci. Discuss., https://doi.org/10.5194/nhess-2018-270

Manuscript under review for journal Nat. Hazards Earth Syst. Sci.

Discussion started: 25 September 2018

(c) Author(s) 2018. CC BY 4.0 License.
Natural Hazards and Earth System Sciences

Discussions
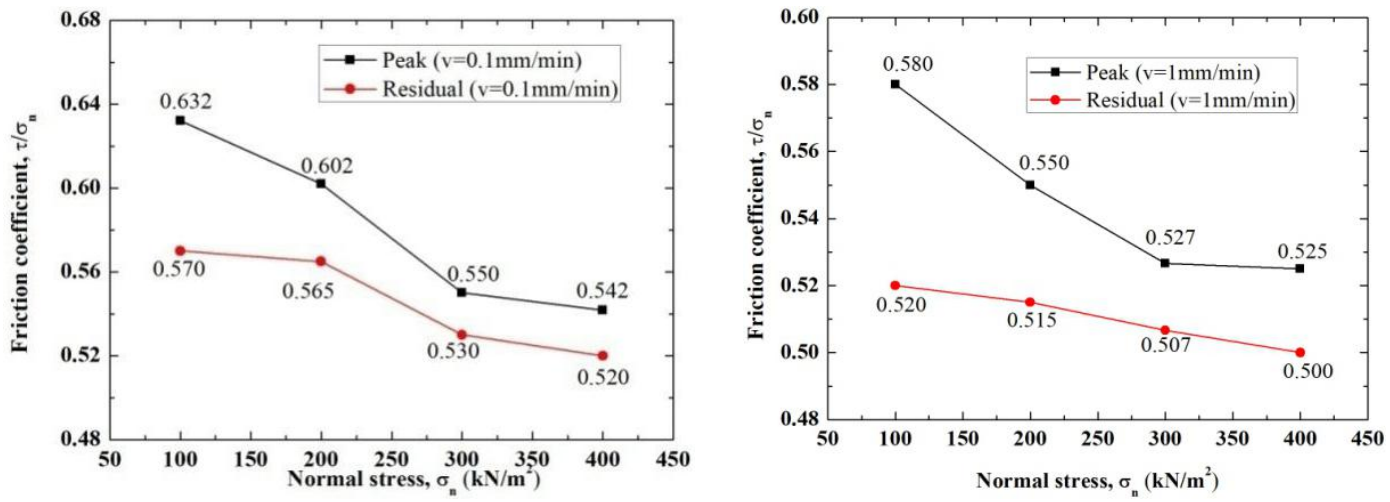

(b) Relationship between friction coefficient and normal stress

Figure 4. Shear behavior characteristics of Ydg soil samples
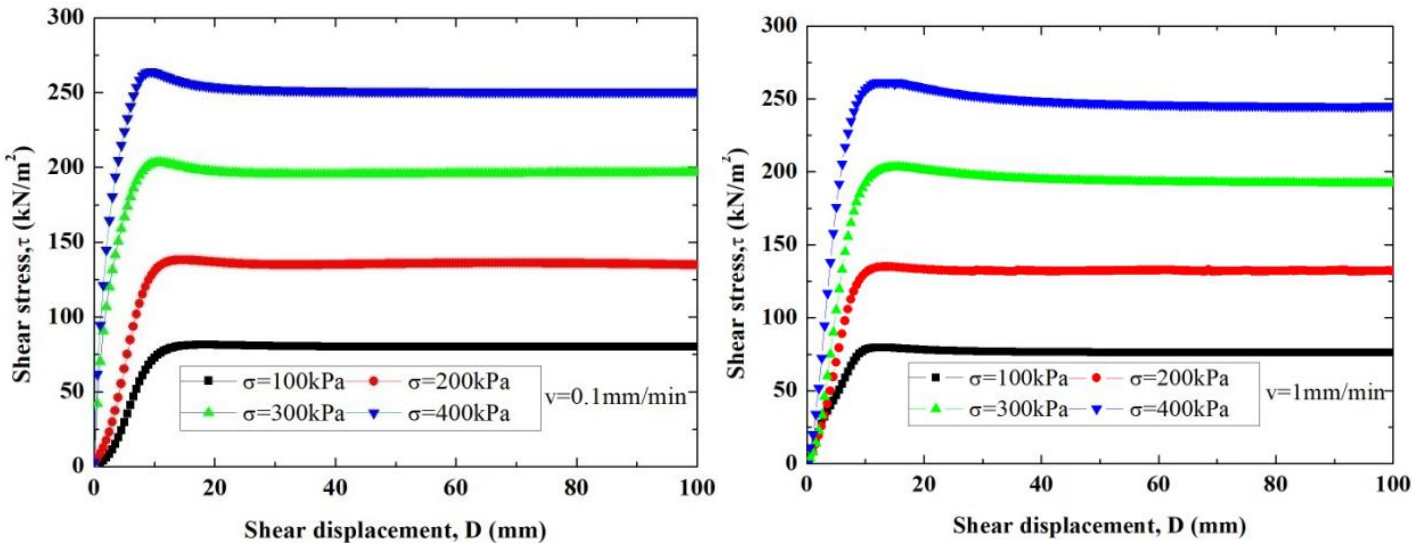

(a) Relationship between shear stress and shear displacement
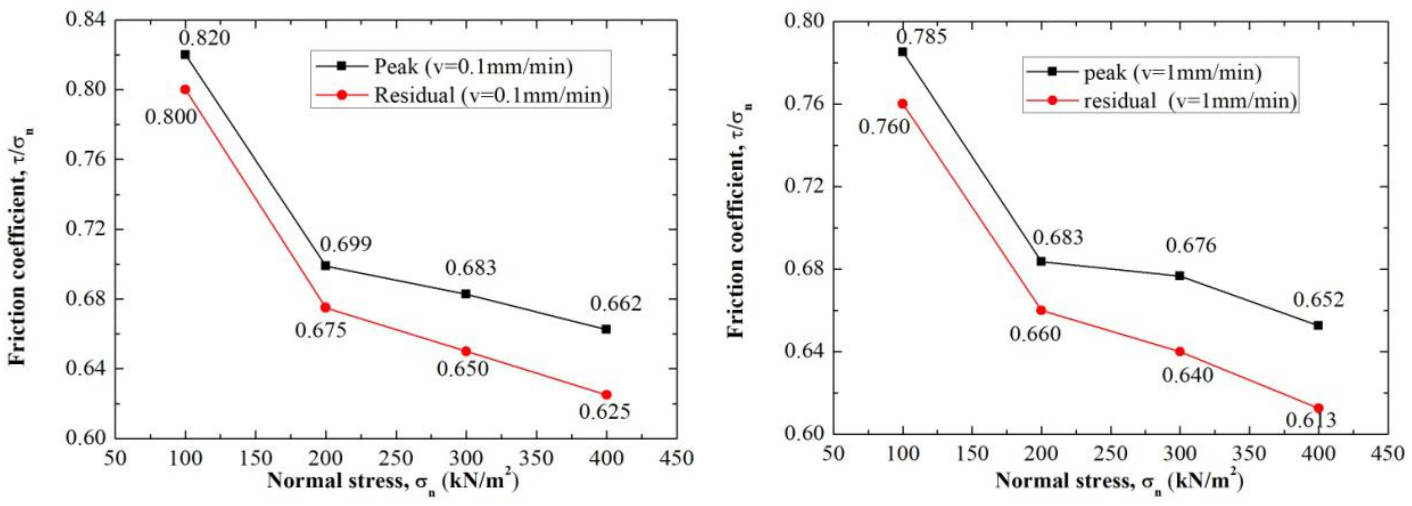

(b) Relationship between friction coefficient and normal stress

Figure 5. Shear behavior characteristics of the Dbz soil samples 
Nat. Hazards Earth Syst. Sci. Discuss., https://doi.org/10.5194/nhess-2018-270

Manuscript under review for journal Nat. Hazards Earth Syst. Sci.

Discussion started: 25 September 2018

(c) Author(s) 2018. CC BY 4.0 License.
Natural Hazards

and Earth System

Sciences

Discussions

\subsection{Effects of shearing rate on residual strength parameter}

For the representative samples described above, Figures 6,7 and 8 show the relationships between the residual friction coefficient and the normal stress, and the residual strength parameters. The residual friction coefficient is plotted against the normal stress. The residual friction coefficient is defined as the residual shear strength divided by normal stress. It is widely recognized that the shear strength parameters including cohesion and friction angle (Terzaghi, 1951;Stark et al., 2005). However, according to the previous studies, the residual angle of soils varies depended on the soil properties as well as the magnitude of normal stress provided the residual cohesion of soil is zero (Skepmton, 1964;Bishop, 1971;Kimura et al., 2014). Thus, in this study, the residual frictions are calculated by Coulomb's law assumed the residual cohesion is zero. The residual strength parameters were defined as $\phi_{\mathrm{r}}(0.1)$ and $\phi_{\mathrm{r}}(1)$ at the low shearing rate and high shearing rate, respectively. And the difference between the residual friction angles at two shearing rate was defined as $\phi_{\mathrm{r}}(1)-\phi_{\mathrm{r}}(0.1)$. Comparatively, the residual friction coefficient was defined $\operatorname{as} \tau_{\mathrm{r}} / \sigma_{\mathrm{n}}(0.1)$ at the low shearing rate and $\tau_{\mathrm{r}} / \sigma_{\mathrm{n}}(1)$ at the high shearing rate, respectively. Furthermore, the difference between the residual friction coefficients was defined as $\tau_{\mathrm{r}} / \sigma_{\mathrm{n}}(1)-\tau_{\mathrm{r}} / \sigma_{\mathrm{n}}(0.1)$. Table 2 summarized the residual parameters of the landslide soils.

Figure 6 shows that the residual friction coefficients were relatively low in $\operatorname{Djg}$ samples. The coefficients $\tau_{\mathrm{r}} / \sigma_{\mathrm{n}}(0.1)$ and $\tau_{\mathrm{r}} / \sigma_{\mathrm{n}}(1)$ at the normal stress of $100 \mathrm{kN} / \mathrm{m}^{2}$ to $400 \mathrm{kN} / \mathrm{m}^{2}$ ranged from 0.3 to 0.262 and from 0.3 to 0.24 ,respectively. The difference between the friction coefficients, $\tau_{\mathrm{r}} / \sigma_{\mathrm{n}}(1)-\tau_{\mathrm{r}} / \sigma_{\mathrm{n}}(0.1)$, at each normal stress level are varied in a range of -0.022 to +0.002 . For the difference between the residual friction angles, $\phi_{\mathrm{r}}(1)-\phi_{\mathrm{r}}(0.1)$, ranged from $-1.212^{\circ}$ to $+0.079^{\circ}$ (Table 2 ). For normal stress above $200 \mathrm{kN} / \mathrm{m}^{2}$, the coefficient $\tau_{\mathrm{r}} / \sigma_{\mathrm{n}}(0.1)$ was found to be greater in the magnitude than the coefficient $\tau_{\mathrm{r}} / \sigma_{\mathrm{n}}(1)$.
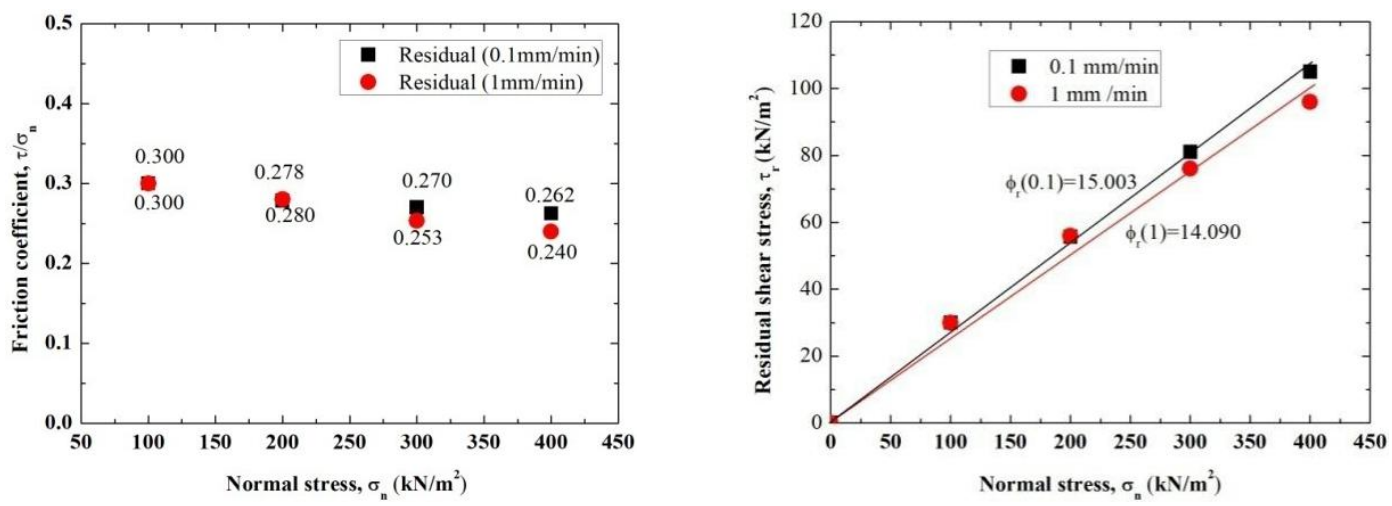
Nat. Hazards Earth Syst. Sci. Discuss., https://doi.org/10.5194/nhess-2018-270

Manuscript under review for journal Nat. Hazards Earth Syst. Sci.

Discussion started: 25 September 2018

(c) Author(s) 2018. CC BY 4.0 License.
Natural Hazards

and Earth System

Sciences

Discussions

Figure 6. Relationships between residual shear stress and normal stress, and residual strength parameter for Djg soil sample

Figure 7 gives the relationship between the residual coefficient and normal stress, and residual shear strength parameter for Ydg samples. The coefficients $\tau_{\mathrm{r}} / \sigma_{\mathrm{n}}(0.1)$ and $\tau_{\mathrm{r}} / \sigma_{\mathrm{n}}(1)$ under the normal stress of $100 \mathrm{kN} / \mathrm{m}^{2}$ to $400 \mathrm{kN} / \mathrm{m}^{2}$ ranged from 0.57 to 0.52 and from 0.52 to 0.50 , respectively. Furthermore, the difference $\tau_{\mathrm{r}} / \sigma_{\mathrm{n}}(1)-\tau_{\mathrm{r}} / \sigma_{\mathrm{n}}(0.1)$ at each normal stress was from -0.05 to -0.02 . As for the difference between the residual friction angles, $\phi_{\mathrm{r}}(1)-\phi_{\mathrm{r}}(0.1)$, was in a range of $-2.218^{\circ}$ to $-0.909^{\circ}$. In case of Ydg soil sample, there was insignificant reduction in residual friction coefficients with the increasing of shearing rate for all normal stresses.
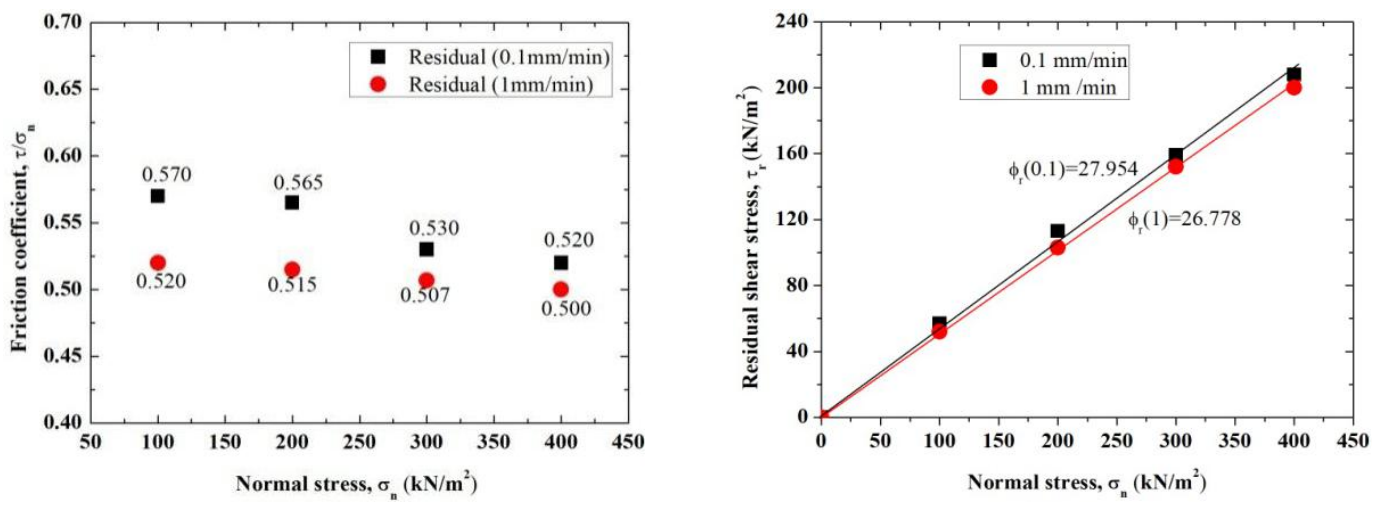

Figure 7. Relationships between residual shear stress and normal stress, and residual strength parameter for Ydg soil sample

Figure 8 presents the results of the Dbz samples. The coefficients $\tau_{\mathrm{r}} / \sigma_{\mathrm{n}}(0.1)$ and $\tau_{\mathrm{r}} / \sigma_{\mathrm{n}}(1)$ at the normal stress of $100 \mathrm{kN} / \mathrm{m}^{2}$ to $400 \mathrm{kN} / \mathrm{m}^{2}$ ranged from 0.8 to 0.625 and from 0.76 to 0.613 , respectively. The difference $\tau_{\mathrm{r}} / \sigma_{\mathrm{n}}(1)-\tau_{\mathrm{r}} / \sigma_{\mathrm{n}}(0.1)$ at each normal stress was from -0.04 to -0.01 . The difference $\phi_{\mathrm{r}}(1)-\phi_{\mathrm{r}}(0.1)$ was from $-1.425^{\circ}$ to $-0.405^{\circ}$. For Dbz samples, there was somewhat decrease of the residual friction coefficients with the increasing of the shearing rate for all normal stress levels. It is noted that the maximum difference was found at the lowest normal stress of $100 \mathrm{kN} / \mathrm{m}^{2}$.

Table 2 summarizes residual strength parameters including $\phi_{\mathrm{r}}(0.1)$ and $\phi_{\mathrm{r}}(1)$ of all specimens obtained from the ring shear tests in this study. As for the Djg samples, the residual strength parameter $\phi_{\mathrm{r}}(0.1)$ and $\phi_{\mathrm{r}}(1)$ for all normal stress were 
Nat. Hazards Earth Syst. Sci. Discuss., https://doi.org/10.5194/nhess-2018-270

Manuscript under review for journal Nat. Hazards Earth Syst. Sci.

Discussion started: 25 September 2018

(c) Author(s) 2018. CC BY 4.0 License.
Natural Hazards

and Earth System

Sciences

Discussions

found to be $15.003^{\circ}$ and $14.09^{\circ}$, respectively. However, the residual friction angles $\phi_{\mathrm{r}}(0.1)$ and $\phi_{\mathrm{r}}(1)$ of the Ydg samples were obtained to be $27.954^{\circ}$ and $26.778^{\circ}$, respectively. In the case of Dbz sample, the friction angles $\phi_{\mathrm{r}}(0.1)$ and $\phi_{\mathrm{r}}(1)$ were high, $32.822^{\circ}$ and $32.293^{\circ}$, respectively. The residual friction angles $\phi_{\mathrm{r}}(0.1)$ and $\phi_{\mathrm{r}}(1)$ under all normal stresses were from $15.003^{\circ}$ to $32.822^{\circ}$ and from $14.09^{\circ}$ to $32.293^{\circ}$, respectively.

Due to the influence of the shearing rate, the difference $\phi_{\mathrm{r}}(1)-\phi_{\mathrm{r}}(0.1)$ in the Djg, Ydg and Dbz samples, were $-0.913^{\circ}$, $-1.176^{\circ}$ and $-0.529^{\circ}$, respectively. Wang (2014) and Fan et al. (2017) asserted that the residual shear strength of remoulded loess hardly affected by shearing rate below $5 \mathrm{~mm} / \mathrm{min}$. However, the results in this study shown that $\phi_{\mathrm{r}}(1)-\phi_{\mathrm{r}}(0.1)$ under all normal stress levels were negative for slip zone loess. Moreover, the maximum value of the difference $\phi_{\mathrm{r}}(1)-\phi_{\mathrm{r}}(0.1)$ even reached about $1.176^{\circ}$.
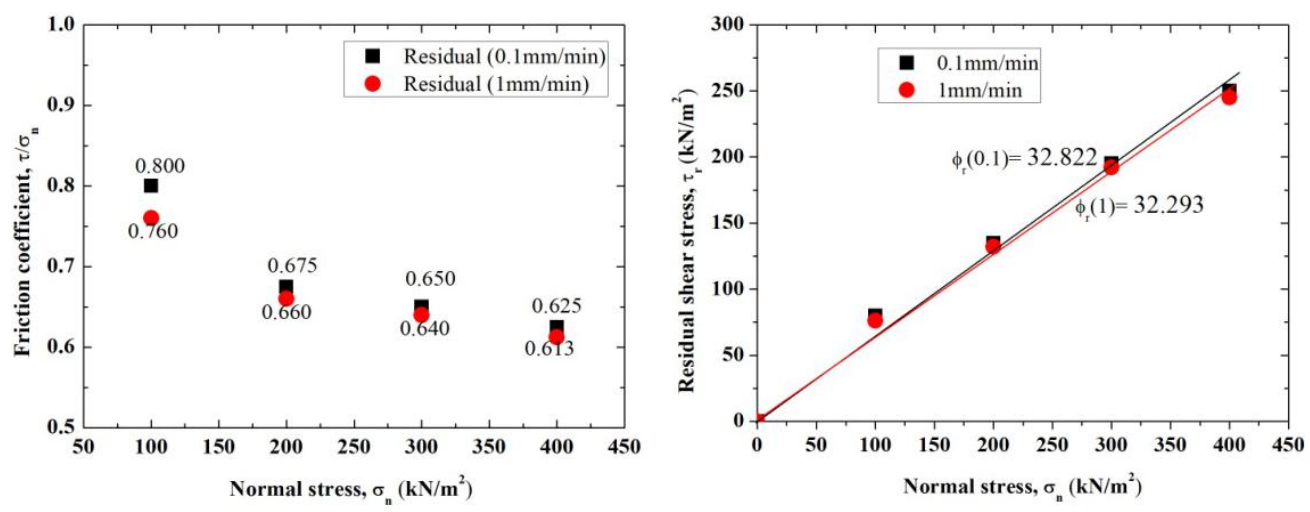

Figure 8. Relationships between residual shear stress and normal stress, and residual strength parameter for Dbz soil sample

Table 2 Residual shear strength parameter of landslide soils

\begin{tabular}{|c|c|c|c|c|c|c|c|c|}
\hline \multirow[t]{3}{*}{$\mathrm{N}$} & \multirow{3}{*}{$\begin{array}{l}\text { Sam } \\
\text { ple }\end{array}$} & \multirow{3}{*}{$\begin{array}{l}\text { Normal } \\
\operatorname{stress}\left(\mathrm{kN} / \mathrm{m}^{2}\right)\end{array}$} & \multicolumn{4}{|c|}{ Residual strength parameter } & \multirow{2}{*}{\multicolumn{2}{|c|}{$\begin{array}{l}\text { Difference } \\
\text { parameter } \\
\phi_{\mathrm{r}(1)^{-}} \\
\text {(Degrees) }\end{array}$}} \\
\hline & & & \multicolumn{2}{|c|}{$\begin{array}{l}0.1 \mathrm{~mm} / \mathrm{min} \quad \phi_{\mathrm{r}} \\
\left(\mathrm{c}_{\mathrm{r}(0.1)}=0\right)(\text { Degrees })\end{array}$} & \multicolumn{2}{|c|}{$\begin{array}{l}1 \quad \mathrm{~mm} / \mathrm{min} \quad \phi_{\mathrm{r}(1)} \\
\left(\mathrm{c}_{\mathrm{r}(1)}=0\right) \text { (Degrees) }\end{array}$} & & \\
\hline & & & $\begin{array}{c}\text { Under each } \\
\qquad \sigma_{\mathrm{n}}\end{array}$ & $\begin{array}{l}\text { Under all } \\
\qquad \sigma_{\mathrm{n}}\end{array}$ & $\begin{array}{l}\text { Under } \\
\text { each } \sigma_{\mathrm{n}}\end{array}$ & $\begin{array}{l}\text { Under } \\
\text { all } \sigma_{\mathrm{n}}\end{array}$ & $\begin{array}{l}\text { Under } \\
\text { each } \sigma_{\mathrm{n}}\end{array}$ & $\begin{array}{l}\text { Under } \\
\text { all } \sigma_{\mathrm{n}}\end{array}$ \\
\hline
\end{tabular}


Nat. Hazards Earth Syst. Sci. Discuss., https://doi.org/10.5194/nhess-2018-270

Manuscript under review for journal Nat. Hazards Earth Syst. Sci.

Discussion started: 25 September 2018

(c) Author(s) 2018. CC BY 4.0 License.
Natural Hazards 웅 and Earth System Sciences

Discussions

(c) (1)

\begin{tabular}{|c|c|c|c|c|c|c|c|c|}
\hline \multirow[t]{4}{*}{1} & Djg & 100 & 16.699 & \multirow[t]{4}{*}{15.003} & 16.699 & \multirow[t]{4}{*}{14.090} & 0 & \multirow[t]{4}{*}{-0.913} \\
\hline & & 200 & 15.563 & & 15.642 & & 0.079 & \\
\hline & & 300 & 15.110 & & 14.216 & & -0.894 & \\
\hline & & 400 & 14.708 & & 13.496 & & -1.212 & \\
\hline \multirow[t]{4}{*}{2} & Ydg & 100 & 29.683 & \multirow[t]{4}{*}{27.954} & 27.474 & \multirow[t]{4}{*}{26.778} & -2.209 & \multirow[t]{4}{*}{-1.176} \\
\hline & & 200 & 29.466 & & 27.248 & & -2.218 & \\
\hline & & 300 & 27.923 & & 26.870 & & -1.053 & \\
\hline & & 400 & 27.474 & & 26.565 & & -0.909 & \\
\hline \multirow[t]{4}{*}{3} & $\mathrm{Dbz}$ & 100 & 38.660 & \multirow[t]{4}{*}{32.822} & 37.235 & \multirow[t]{4}{*}{32.293} & -1.425 & \multirow[t]{4}{*}{-0.529} \\
\hline & & 200 & 34.019 & & 33.425 & & -0.594 & \\
\hline & & 300 & 33.024 & & 32.619 & & -0.405 & \\
\hline & & 400 & 32.005 & & 31.487 & & -0.518 & \\
\hline
\end{tabular}

\section{Influence of the shearing rate on the residual friction angles according to soil properties}

Figure 9 depicts the relationships between residual friction angles as well as the difference in the residual friction angles and soil properties including liquid limit (LL), plasticity index (Ip) and clay fraction (CF) at two shearing rates. The residual friction angles at two shearing rates decreased nonlinearly with the increasing of the LL. As for the relationship between the $\phi_{\mathrm{r}}$ and Ip, the $\phi_{\mathrm{r}}$ under the low and high shearing rates decreases from about $32^{\circ}$ to $15^{\circ}$ with increasing the plasticity index from 11 to 16 . With increasing of CF from $9 \%$ to $24 \%$, the residual friction angles under low and high shearing rates were found to decrease. Interestingly, for Dbz and Ydg soils of which have similar percentage of clay fraction, the residual friction angles at both shearing rates varied. However, in the relationships between the difference in the residual friction angles and the soil properties, no clear correlations were found. 
Nat. Hazards Earth Syst. Sci. Discuss., https://doi.org/10.5194/nhess-2018-270

Manuscript under review for journal Nat. Hazards Earth Syst. Sci.

Discussion started: 25 September 2018

(c) Author(s) 2018. CC BY 4.0 License.

\section{(c) (1)}
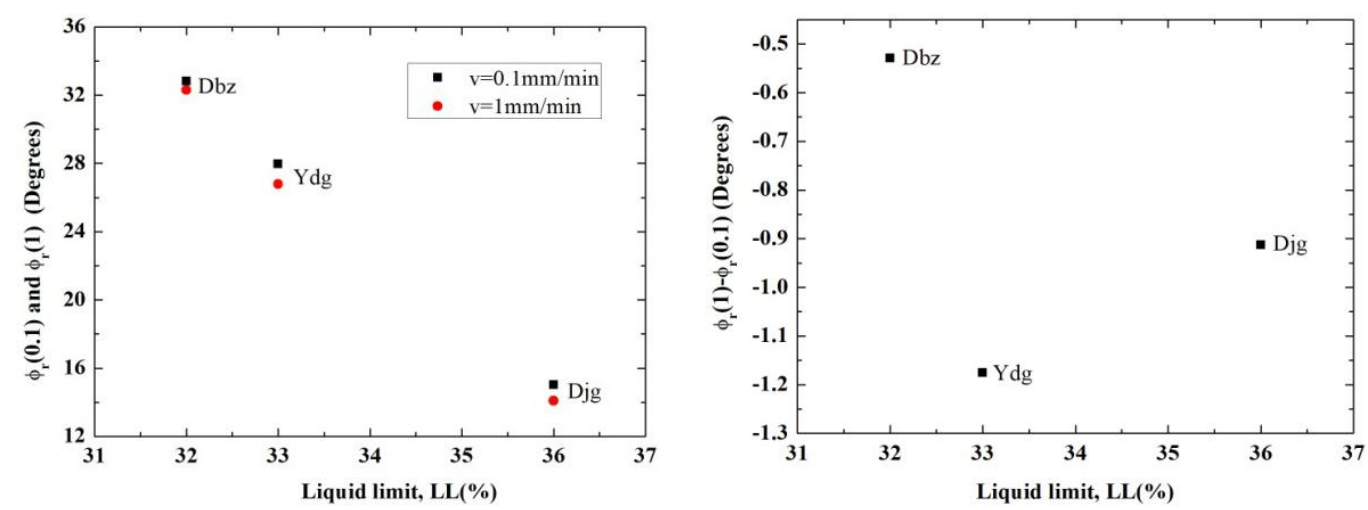

304
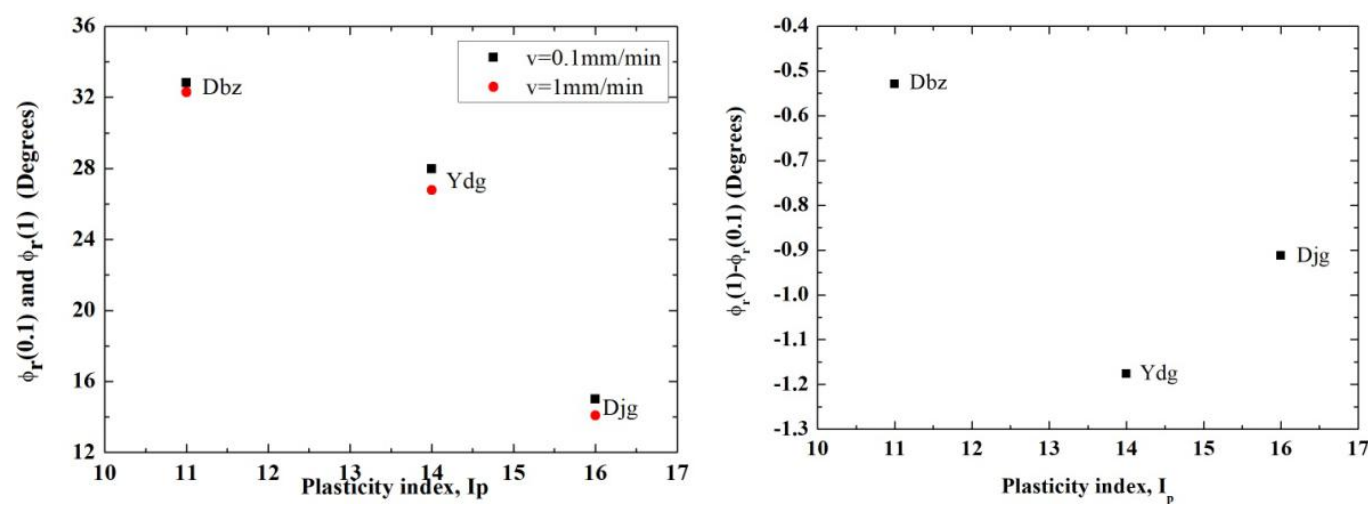

306
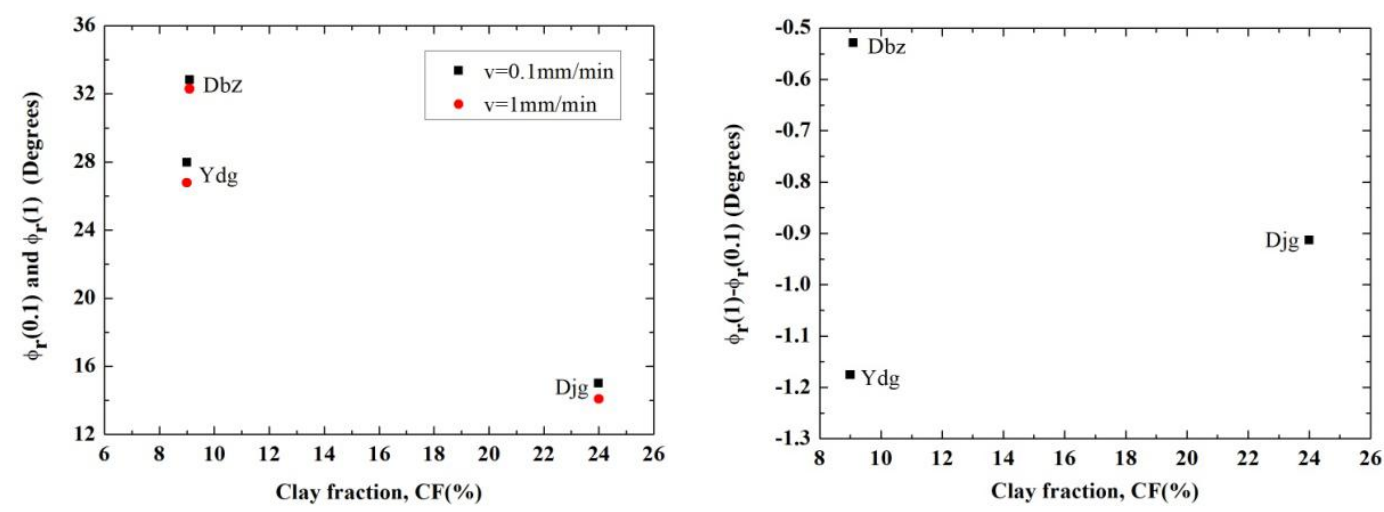

Figure 9. Relationships between residual shear parameter, the difference in residual shear parameter and the soil properties at two shearing rates 
Nat. Hazards Earth Syst. Sci. Discuss., https://doi.org/10.5194/nhess-2018-270

Manuscript under review for journal Nat. Hazards Earth Syst. Sci.

Discussion started: 25 September 2018

(c) Author(s) 2018. CC BY 4.0 License.

(c) (i)

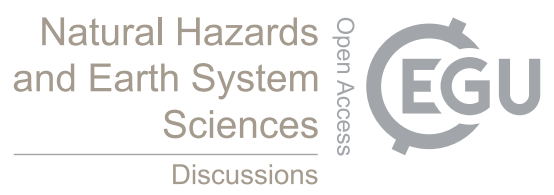

\section{Conclusions}

312 The shearing rate of slip zone soil of landslide may be changed after the occurrence of the first landslide activity, thus, the 313 residual shear strength of the slip zone soil could be changed accompanying this process. As for some precision engineering which require high accuracy of the design parameters, the shearing rate effect on the residual shear strength should be fully

315 investigated. In this study, at the shearing rate of $0.1 \mathrm{~mm} / \mathrm{min}$ and $1 \mathrm{~mm} / \mathrm{min}$, a series of ring shear tests under normal stress 316 ranged from $100 \mathrm{kN} / \mathrm{m}^{2}$ to $400 \mathrm{kN} / \mathrm{m}^{2}$ were performed on reconstituted slip zone soil samples obtained from three landslides 317 in loess area. The main results can be summarized in the following points:

318 (i) The shear displacement to achieve the residual stage for specimens with higher shearing rate is greater than that of

(ii) As for slip zone soils in this study, specimens with lower shearing rate attained greater friction coefficients than that with higher shearing rate.

(iii) At the two shearing rate $(0.1 \mathrm{~mm} / \mathrm{min}$ and $1 \mathrm{~mm} / \mathrm{min})$, the residual friction coefficient under the lower normal stress was higher than that under the higher normal stress in all samples. In addition, there was a nonlinearly decrease trend of the residual friction with the normal stress.

(v) The residual friction angles reduce with the increasing of shearing rate. Furthermore, the maximum magnitude of in loess area.

(iv) For slip zone soils in this study, the difference at the two shearing rate, $\phi_{\mathrm{r}}(1)-\phi_{\mathrm{r}}(0.1)$, under each normal stress level were either negative or positive. However, under all normal stress, the difference at the two shearing rate $\phi_{\mathrm{r}}(1)-\phi_{\mathrm{r}}(0.1)$ was found to be positive. 
Nat. Hazards Earth Syst. Sci. Discuss., https://doi.org/10.5194/nhess-2018-270

Manuscript under review for journal Nat. Hazards Earth Syst. Sci.

Discussion started: 25 September 2018

(c) Author(s) 2018. CC BY 4.0 License.

(c) (1)

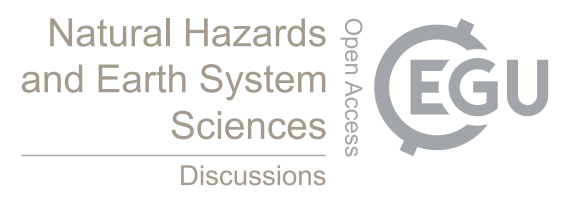

$338 \quad$ Acknowledgments

339 Financial support of National Key Fundamental Research Program of China (973) (Grant No.2014CB744700) and the Major

340 Program of National Natural Science Foundation of China (Grant No. 41790440) are gratefully acknowledged. The support 341 provided by China Scholarship Council (CSC file No. 201706560016) during a visit of the first author (Lian) to Texas A\&M 342 University is sincerely acknowledged. 
Nat. Hazards Earth Syst. Sci. Discuss., https://doi.org/10.5194/nhess-2018-270

Manuscript under review for journal Nat. Hazards Earth Syst. Sci.

Discussion started: 25 September 2018

(c) Author(s) 2018. CC BY 4.0 License.
Natural Hazards

and Earth System

Sciences

Discussions

\section{Reference}

Bhat, D. R.: Effect of shearing rate on residual strength of kaolin clay, $\mathrm{PhD}$, Graduate school of Science and Engineering, Ehime University, Ehime University, Japan, 2013.

Bishop, A. W.: Shear strength parameters for undisturbed and remoulded specimens., Proc the Roscoe Memorial Symp, Foulis and Co, 1971, 3-58.,

Bishop, A. W., Green, G. E., Garga, V. K., Andresen, A., and Brown, J. D.: A new ring shear apparatus and its application to the measurement of residual strength, Geotechnique, 21, 273-328, 10.1680/geot.1971.21.4.273, 1971.

Bromhead, E.: A simple ring-shear apparatus, Ground Engineering, 12, 40-44, 1979.

Bromhead, E.: The stability of slopes, blackie academic and professional, London. UK, 1992.

Chen, X. P., and Liu, D.: Residual strength of slip zone soils, Landslides, 11, 305-314, 10.1007/s10346-013-0451-z, 2013.

Eid, H. T.: Stability charts for uniform slopes in soils with nonlinear failure envelopes, Engineering Geology, 168, 38-45, 10.1016/j.enggeo.2013.10.021, 2014.

Fan, X., Xu, Q., Scaringi, G., Li, S., and Peng, D.: A chemo-mechanical insight into the failure mechanism of frequently occurred landslides in the Loess Plateau, Gansu Province, China, Engineering Geology, 228, 337-345, 10.1016/j.enggeo.2017.09.003, 2017.

Gonghui, W., Akira, S., and H., S. W.: Shear-rate-dependent strength control on the dynamics of rainfall-triggered landslides, Tokushima Prefecture, Japan, Earth Surface Processes and Landforms, 35, 407-416, doi:10.1002/esp.1937, 2010.

Gratchev Ivan, B., and Sassa, K.: Shear strength of clay at different shear rates, Journal of Geotechnical and Geoenvironmental Engineering, 141, 06015002, 10.1061/(ASCE)GT.1943-5606.0001297, 2015.

Grelle, G., and Guadagno, F. M.: Shear mechanisms and viscoplastic effects during impulsive shearing, Géotechnique 41, 60, 91-103, 10.1680/geot.8.P.019], 2010.

Hoyos, L. R., Velosa, C. L., and Puppala, A. J.: Residual shear strength of unsaturated soils via suction-controlled ring shear testing, Engineering Geology, 172, 1-11, 10.1016/j.enggeo.2014.01.001, 2014. 
Nat. Hazards Earth Syst. Sci. Discuss., https://doi.org/10.5194/nhess-2018-270

Manuscript under review for journal Nat. Hazards Earth Syst. Sci.

Discussion started: 25 September 2018

(c) Author(s) 2018. CC BY 4.0 License.
Natural Hazards

and Earth System

Sciences

Discussions

Jiang, Y., Wang, G., Kamai, T., and McSaveney, M. J.: Effect of particle size and shear speed on frictional instability in sheared granular materials during large shear displacement, Engineering Geology, 210, 93-102, 10.1016/j.enggeo.2016.06.005, 2016.

Kimura, S., Nakamura, S., Vithana, S. B., and Sakai, K.: Shearing rate effect on residual strength of landslide soils in the slow rate range, Landslides, 11, 969-979, 10.1007/s10346-013-0457-6, 2014.

Kimura, S., Nakamura, S., and Vithana, S. B.: Influence of effective normal stress in the measurement of fully softened strength in different origin landslide soils, Soil Till Res, 145, 47-54, 10.1016/j.still.2014.07.018, 2015.

Lemos, L.: Earthquake loading of shear surfaces in slopes, Proc.11th I.C.S.M.F.E., 4, 1955-1958, 1985.

Leng, Y., Peng, J., Wang, Q., Meng, Z., and Huang, W.: A fluidized landslide occurred in the Loess Plateau: A study on loess landslide in South Jingyang tableland, Engineering Geology, 236, 129-136, 10.1016/j.enggeo.2017.05.006, 2018.

Li, Y. R., Wen, B. P., Aydin, A., and Ju, N. P.: Ring shear tests on slip zone soils of three giant landslides in the Three Gorges Project area, Engineering Geology, 154, 106-115, 10.1016/j.enggeo.2012.12.015, 2013.

Lupini, J. F., Skinner, A. E., and Vaughan, P. R.: The drained residual strength of cohesive soils, Geotechnique, 31, 181-213, 10.1680/geot.1981.31.2.181, 1981 .

Mesri, G., and Shahien, M.: Residual shear strength mobilized in first-time slope failures, Journal of Geotechnical and Geoenvironmental Engineering, 129, 12-31, 2003.

Morgenstern, N. R., and Hungr, O.: High Velocity ring shear tests on sand, Geotechnique, 34, 415-421, 1984.

Okada, Y., Sassa, K., and Fukuoka, H.: Excess pore pressure and grain crushing of sands by means of undrained and naturally drained ring-shear tests, Engineering Geology, 75, 325-343, https://doi.org/10.1016/j.enggeo.2004.07.001, 2004.

Sassa, K., Fukuoka, H., Wang, G., and Ishikawa, N.: Undrained dynamic-loading ring-shear apparatus and its application to landslide dynamics, Landslides, 1, 7-19, 10.1007/s10346-003-0004-y, 2004.

Skempton, A. W.: Long-term stability of clay slopes, Geotechnique, 14, 77-102, 1964. 
Nat. Hazards Earth Syst. Sci. Discuss., https://doi.org/10.5194/nhess-2018-270

Manuscript under review for journal Nat. Hazards Earth Syst. Sci.

Discussion started: 25 September 2018

(c) Author(s) 2018. CC BY 4.0 License.
Natural Hazards

and Earth System

Sciences

Discussions
393

394

395

396

397

398

399

400

401

402

403

404

405

406

407

408

409

410

411

412

413

4142000.

Skempton, A. W.: Residual strength of clays in landslides, folded strata and the laboratory, Geotechnique, 35, 3-18, 1680/geot.1985.35.1.3, 1985.

ton: Long-term stability of clay slopes, Geotechnique, 14, 77-102, 1964.

T. D., Choi, H., and McCone, S.: Drained shear strength parameters for analysis of landslides, Journal of echnical and Geoenvironmental Engineering, 131, 575-588, 2005

ark Timothy, D., Choi, H., and McCone, S.: Drained shear strength parameters for analysis of landslides, Journal of

P., Peng, J.-b., Chen, L.-w., Yin, Y.-p., and Wu, S.-r.: Weak tensile characteristics of loess in China - An portant reason for ground fissures, Engineering Geology, 108, 153-159, tps://doi.org/10.1016/j.enggeo.2009.05.014, 2009.

M., Yamamoto, T., and Tanikawa, K.: Variation in residual strength of clay with sharing speed. , Memoir of y of Engineering of Yamagushi University of Toronto Medical Journal, 52, 45-49, 2001.

Tiwari, B., and Marui, H.: Concept of shear strength measurement and modification of stability analysis during 416 countermeasure planning of landslides, Landslides, 38, 213-224, 10.3313/j1s1964.38.3_213, 2001. 
Nat. Hazards Earth Syst. Sci. Discuss., https://doi.org/10.5194/nhess-2018-270

Manuscript under review for journal Nat. Hazards Earth Syst. Sci.

Discussion started: 25 September 2018

(c) Author(s) 2018. CC BY 4.0 License.

(c) (i)

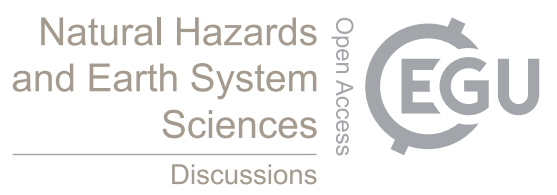

417 Tiwari, B., and Marui, H.: A new method for the correlation of residual shear strength of the soil with mineralogical 418 composition, Journal of Geotechnical and Geoenvironmental Engineering, 131, 1139-1150, 419 10.1061/(ASCE)1090-0241(2005)131:9(1139), 2005.

420 Vithana, S. B., Nakamura, S., Kimura, S., and Gibo, S.: Effects of overconsolidation ratios on the shear strength of 421 remoulded slip surface soils in ring shear, Engineering Geology, 131-132, 29-36, 422 https://doi.org/10.1016/j.enggeo.2012.01.015, 2012.

423 Wang, W.: Residual Strength of Remolded Loess in Ring Shear Tests. PhD thesis. Northwest A \& F University, 424 Shanxi, China., 2014.

425 Yokota, K., Yatabe, R., and Yagi, N.: Strength characteristics of weathered serpentine, Doboku Gakkai Ronbunshu, $4261995,155-163,1995$. 